\title{
ЕКОНОМІКА
}

\begin{tabular}{|c|c|c|}
\hline & $\begin{array}{c}\text { Науковий вісник НЛтУ України } \\
\text { Scientific Bulletin of UNFU } \\
\text { https://nv.nltu.edu.ua }\end{array}$ & \begin{tabular}{|l|l} 
(C) & ISSN 1994-7836 (print) \\
BY ISSN 2519-2477 (online)
\end{tabular} \\
\hline H人า & https://doi.org/10.36930/40300510 & $@ \bowtie$ Correspondence author \\
\hline & $\begin{array}{l}\text { Article received } 03.11 .2020 \mathrm{p} \\
\text { Article accepted } 24.09 .2020 \mathrm{p} \text {. }\end{array}$ & $\begin{array}{r}\text { N. E. Pankiv } \\
\text { pankiv.natalia@gmail.com }\end{array}$ \\
\hline & UDC 338.48-6:502 & \\
\hline
\end{tabular}

Н. Є. Паньків

Національний університет "Львівська політехніка", м. Львів, Україна

\section{ПЕРСПЕКТИВИ ВИКОРИСТАННЯ ТУРИСТИЧНО-РЕКРЕАЦІЙНИХ РЕСУРСІВ ДЛЯ РОЗВИТУ ЗЕЛЕНОГО (СІЛЬСЬКОГО) ТА ЕКОЛОГІЧНОГО ТУРИЗМУ В ІВАНО-ФРАНКІВСЬКІЙ ОБЛАСТІ}

\begin{abstract}
Досліджено туристично-рекреаційні ресурси Івано-Франківщини та визначено перспективи їх використання для розвиту зеленого (сільського) та екологічного туризму в області. Виявлено, що сільський зелений туризм має сприятливі передумови для розвитку, адже в області є пам'ятки історії та культури світового рівня, унікальні природні ландшафти. Найпопулярнішими осередками відпочинку серед туристів є Яремчанський, Верховинський та Косівський райони, зокрема, їх гірські частини, де є розвинена мережа агроосель (загалом в області - близько 800 осель) із різними ціновими пропозиціями. Встановлено, що природні умови та наявність великої кількості об'єктів природно-заповідного фонду в Івано-Франківській області (482 території та об'єкти, площа яких становить 218,9 тис. га, або 15,7 \% від площі області) сприяють розвитку широкого спектра форм екологічного туризму. Виокремлено найперспективніші осередки, які мають високий потенціал для розвитку цього виду туризму в області, зокрема: Косівський, Долинський, Надвірнянський, Городенківський і Верховинський райони та територія Яремчанської міської ради. З'ясовано, що Івано-Франківську область формують різноманітні етнографічні райони - Покуття, Гуцульщини, Бойківщини та Опілля. Корінне населення цих районів досі зберігає багату матеріально-духовну спадщину, особливий давньоукраїнський колорит, який наповнений самобутніми обрядами, одягом, побутом, ремеслами, архітектурою, що, безумовно, є атрактивним для великої кількості туристів, що сприяє розвитку в регіоні також етнографічного туризм. Отже, доцільно розвивати в області такі напрями туристичної діяльності, як інтерактивні скансени, агроготелярство, контактні зоопарки, іпотерапія та апітерапія, а також відвідування історичних сільських місцевостей та участь в етнофестивалях і різноманітних майстер-класах з виготовлення народних ремесел. Все це зумовить розвиток "безпечного" туризму в області, такого, що буде сприяти збереженню навколишнього середовища та раціональному використанню туристично-рекреаційних ресурсів Івано-Франківщини та забезпечить роботою місцевих мешканців, що, відповідно, зумовить економічне зростання регіону загалом.

Ключові слова: природно-ресурсний потенціал; рекреаційна цінність; сільські території; об'єкти природно-заповідного
\end{abstract} фонду; розвиток "безпечного" туризму.

\section{Вступ}

Для Івано-Франківщини характерними є багатий природно-ресурсний потенціал та історико-культурна спадщина, що позитивно впливає на розвиток туризму в регіоні. Безумовно, серед розмаїття способів та можливостей відпочинку в області, найперспективнішим стає сільський зелений туризм, який забезпечує роботою місцеве населення та сприяе економічному зростанню бюджету місцевих територіальних громад загалом.

Серед населення Івано-Франківщини близько 57 \% становлять мешканці сіл, загальна кількість яких в області - 765. Така велика кількість людських ресурсів сприятиме розвитку туризму в сільських громадах. Окрім цього, мешканці Івано-Франківщини, які належать до різноманітних етнографічних районів (Покуття, Гуцульщини, Бойківщини та Опілля), досі зберігають ба- гату матеріально-духовну спадщину, особливий давньоукраїнський колорит, який наповнений самобутніми обрядами, одягом, побутом, ремеслами, архітектурою, що привертає велику увагу туристів.

Природне різноманіття регіону, зокрема, гірська частина Українських Карпат, вкрита лісами, з розмаїттям рослинного та тваринного світу, багато з яких занесено до Червоної книги, а також водні ресурси регіону - гірські, швидкоплинні річки з великою кількістю каскадів та водоспадів, зумовлюють велику рекреаційну цінність області. До прикладу, активно розвиваються такі види туризму, як пішохідний, велосипедний та кінний, екологічний, сільський, зелений та водний туризм. Однак, на сьогодні практично відсутні рекомендації щодо розумних перспектив використання туристичнорекреаційних ресурсів для ефективного розвиту зелено-

\section{Інформація про автора:}

Паньків Наталія Євгенівна, канд. біол. наук, доцент, кафедра туризму Інституту сталого розвитку ім. В. Чорновола. Email: pankiv.natalia@gmail.com; https://orcid.org/0000-0002-9057-9612

Цитування за ДстУ: Паньків Н. Є. Перспективи використання туристично-рекреаційних ресурсів для розвиту зеленого (сільського) та екологічного туризму в Івано-Франківській області. Науковий вісник НЛтУ України. 2020, т. 30, № 5. С. 59-60. Citation APA: Pankiv, N. Е. (2020). Prospects for the use of tourist and recreational resources for the development of green (rural) and ecological tourism in Ivano-Frankivsk region. Scientific Bulletin of UNFU, 30(5), 59-60. https://doi.org/10.36930/40300510 
го (сільського) та екологічного туризму в Івано-Франківській області. 3 огляду на зазначене вище, тема дослідження є актуальною.

Об'єкт дослідження - сучасний стан та тенденції розвитку зеленого (сільського) та екологічного туризму.

Предмет дослідження - методи і засоби визначення перспектив використання туристично-рекреаційних ресурсів для розвиту зеленого (сільського) та екологічного туризму в Івано-Франківській області.

Мета роботи - дослідити особливості функціонування та розвиток зеленого (сільського) та екологічного туризму на Івано-Франківщині.

Для досягнення зазначеної мети визначено такі основні завдання дослідження: дослідити туристичнорекреаційні ресурси Івано-Франківщини та визначити перспективи їх використання для розвиту зеленого (сільського) та екологічного туризму в області.

Наукова новизна отриманих результатів дослідження - вперше розроблено методику, яка дає змогу проаналізувати туристично-рекреаційні ресурси Івано-Франківщини та визначено перспективи їх використання для розвиту зеленого (сільського) та екологічного туризму в області, що забезпечить зростання рівня добробуту місцевого населення й наповнення бюджету їхніх громад.

Практична значущість результатів дослідження сприятимуть розширенню переліку туристичних і туристично-інформаційних послуг, промоції туристичного потенціалу області, збільшенню кількості туристів і розвитку зеленого (сільського) та екологічного туризму в області, що зумовить збільшення кількості робочих місць й зростання рівня добробуту місцевого населення та наповнення бюджету як їхніх громад, так і внесків у державний бюджет.

Матеріали та методи дослідження. У процесі дослідження застосовували аналітичний та порівняльно-географічний методи, а також методи узагальнення та систематизації.

Аналіз останніх досліджень та публікацій. Великий внесок у виявлення і дослідження проблемних питань розвитку зеленого (сільського) та екологічного туризму зробили вчені п. Горішевський, Ю. Зінько, М. Рутинський та багато інших $[6,15,16,21]$. Підсумовуючи дослідження щодо використання в обігу понять "сільський туризм", "зелений туризм", "сільський зелений туризм", "агротуризм" та "екотуризм", варто констатувати, що вони мають багато схожих рис, оскільки характеризують вид відпочинку в сільській місцевості. Водночас, існує низка відмінностей, які розмежовують ці дефініції. Сільський зелений туризм та екотуризм $\epsilon$ близькими за змістом поняттями, проте між ними існує різниця насамперед в об'єкті. Об'єктом екотуризму є природа (первинні, незаймані діяльністю людини ландшафти), а об'єктом сільського зеленого туризму - надбання культурно-історичної та господарської діяльності людини. Другою відмінністю $\epsilon$ те, що екотуризм передбачає заняття різними формами активної рекреації (піші прогулянки, велосипедний, водний спорт, збиральництво, рибальство) у природному навколишньому середовищі без заподіяння йому шкоди, а сільський зелений туризм - це тимчасове переміщення туристів у сільську місцевість із метою відпочинку та ознайомлення 3 місцевим способом життя, традиціями, звичаями. Отже, домогосподарства, розташовані в сільській місцевості, функціонуючи як приватні селянські господарства, можуть реалізувати свою виробничу функцію й у сфері сільського зеленого туризму [1].

Водночас, комплекс науково-практичних проблем, пов'язаних із функціонуванням цих видів туризму, їх впливом на аспекти життя сільського населення та розвиток економіки, залишається недостатньо дослідженим у зарубіжній та вітчизняній науковій літературі.

\section{Результати дослідження та їх обговорення}

В Івано-Франківській області ще в 1996 р. для промоції сільського зеленого туризму було створено "Івано-Франківську обласну організацію Спілки сприяння розвитку сільського зеленого туризму в Україні. Основні іiі завдання: організація та проведення тренінгів та семінарів, розроблення маршрутів і турів, створення та просування турпродукту, категоризація та сертифікація агросадиб" [11]. Окрім цього, з 2003 р. в Івано-Франківську діє Регіональний туристично-інформаційний центр (РТІЦ), який консолідує вміння, навички та зусилля фахівців сфери туризму для навчання місцевих мешканців задля розвитку сільського зеленого туризму в регіоні.

На Івано-Франківщині, завдяки розмаїттю природних ресурсів, є безліч можливостей комбінувати спокійний відпочинок в агрооселях 3 великою кількістю активних видів відпочинку. Це сприяло створенню на початку XXI ст. потужної мережі агроосель у Карпатському регіоні, які активно рекламують свої послуги на Інтернет-ресурсах, зокрема, нещодавно створено два туристичні веб-портали: discover.if.ua, www.iftourism.com. [9, 10, 11].

Здійснивши аналіз даних найпопулярніших інтернет-сайтів, які надають інформацію про агросадиби Івано-Франківщнини (загалом їх близько 800) та різноманітні послуги, які вони надають туристам для незабутнього відпочинку в сільській місцевості, можна констатувати, що в Івано-Франківській області великим попитом користуються агросадиби, розміщені на Яремчанщині та у гірській частині Верховинського та Косівського районів області.

Аналізуючи територіальний розподіл агроосель по території області, здійснено групування адміністративних одиниць Івано-Франківщини за показником кількості приватних осель сільського зеленого туризму, що припадає на 1000 осіб сільського населення (таблиця).

Отже, залежно від рівня розвитку туристичної інфраструктури, особливостей пропонованого туристичного продукту, наявності туристично-рекреаційних ресурсів та атрактивності території, в межах гірської частини Івано-Франківщини М. Рутинський виділяє три різні туристичні райони, сприятливі для розвитку сільського зеленого туризму, зокрема: "ВорохтинськоЯремчанський, Верховинсько-Косівський і Осмолодсько-Болехівський райони. Найпопулярнішим серед туристів є Ворохтинсько-Яремчанський туристичний район, в якому розміщено близько $2 / 3$ гірських туристичних комплексів області та понад 50 \% садиб сільського зеленого туризму Івано-Франківщини. Наступний за кількістю туристичних потоків області - Верховинсько-Косівський туристичний район, з його двома потужними туристичними центрами у Косові та Верховині. А от Осмолодсько-Болехівський туристичний район не відзначається великою популярністю, хоча $є$ потен- 
ційно найперспективнішим для розвитку туризму серед інших районів, оскільки він межує з великими бальнеологічними курортами заходу України (Трускавець, Моршин), з популярними гірськолижними курортами у
Львівській області (Славське, Сколе) і на Закарпатті (Воловець, Міжгір'я), а також з мальовничими Національними природними парками "Сколівські Бескиди" i "Синевир" [15].

Таблиця. Рівень розвитку сільського зеленого туризму в Івано-Франківській області [15]

\begin{tabular}{|l|c|c|}
\hline \multicolumn{1}{|c|}{ Назва адміністративної одиниці } & $\begin{array}{c}\text { Кількість агроосель на 1000 } \\
\text { осіб сільського населення }\end{array}$ & $\begin{array}{c}\text { Рівень розвитку інфраструкту- } \\
\text { ри сільського зеленого туризму }\end{array}$ \\
\hline $\begin{array}{l}\text { Івано-Франківська міська рада, Коломийська міська рада, Калусь- } \\
\text { ка міська рада, Калуський, Галицький, Городенківський, Сня- } \\
\text { тинський райони }\end{array}$ & не виявлено \\
\hline $\begin{array}{l}\text { Болехівська міська рада, Богородчанський, Тисменицький, Тлу- } \\
\text { мацький райони, Долинський, Коломийський, Косівський, Над- } \\
\text { вірнянський, Рожнятівський }\end{array}$ & $0,01-2,0$ \\
\hline дерховинський район & $2,1-10,0$ & Незначний розвиток \\
\hline Яремчанська міська рада & Більше 10 & Середній розвиток \\
\hline
\end{tabular}

Істотно менше туристів відвідує передгірно-долинну туристичну зону області, в якій виділяють СнятинськоКоломийський i Рогатинсько-Галицький туристичні райони, очевидно, це зумовлено недостатньою промоцією території на регіональному туристичному ринку.

На Івано-Франківщині комфортні умови проживання, смачні страви традиційної та регіональної Української кухні надають агросадиби, що належать, зокрема, до мережі "Українська гостинна садиба". До прикладу, "Краща садиба сільського зеленого туризму" третьої, найвищої категорії - "Княжий Град" у селі Княждвір Коломийського району. Номерний фонд садиби містить проживання за двома тарифами: "Стандарт" i "Все в одному". А гостинні власники садиби, окрім основних, надають низку додаткових послуг туристам, зокрема, організовують для них екскурсії. До цієї самої категорії належить приватна садиба "Еко-Карпати" у селищі Кути Косівського району, яка розміщена у мальовничому куточку поблизу річки Черемош та гірського масиву Покутсько-Буковинських Карпат. До другої категорії належать: Маєток "12 Місяців", розміщений у центральній частині Карпат, на одному з мальовничих пагорбів села Мислівка (урочище Йозифсталь); садиба "Дарваїв кут" у селі Старий Мізунь, Долинського р-ну та гостинний двір "Горицвіт", який затишно розміщений на березі гірської річки поблизу залісненої гори у селі Верхній Ясенів Верховинського району. До першої категорії належать садиби: "Бойківські світанки" у селі Новошин та "На Бабієвій горі" у селі Оболоня Долинського району і "Ведмежа гора" у селі Космач Косівського району. Окрім цього, послуги туристам надає низка садиб в області, що належать до базової категорії [11].

Як зазначено на Офіційному сайті Головного управління $з$ питань туризму, євроінтеграції, зовнішніх зв'язків та інвестицій: "Ведення реєстру садиб сільського зеленого туризму області $\epsilon$ важливим для потенційних споживачів цих послуг, для надання господарям інформаційних послуг, що стосуються якості обслуговування, нормативно-правових вимог. Проведення екологічної категоризації садиб сільського зеленого туризму області використовується як маркетинговий інструмент, збільшує популярність садиби серед екологічно свідомих туристів. Категоризація приватних садиб забезпечує: прозорість пропозиції для клієнта; контроль якості туристичного продукту; різноманітність пропозиції туристичних послуг та різницю в ціні. Знак надається Спілкою сприяння розвитку сільського зеленого туризму в Україні. Приватні оселі Івано-Франківщини проходять категоризацію на рівень послуг ("Гостинна сади- ба") та екологічність ("Зелена садиба"), що сприяє підвищенню конкурентності турпродуктів" [10]. Загалом організація відпочинку на селі має позитивний вплив на вирішення актуальних соціально-економічних проблем територіальних громад, створення нових робочих місць, формування екологічної свідомості селян і відпочивальників [17].

Активно розвивається на Івано-Франківщині також екологічний туризм, використовуючи численні ресурси, що належать до природоохоронних територій національного та регіонального значення. Як зазначено у документі "Стратегія розвитку Івано-Франківської області на 2021-2027 роки": "Мережа природно-заповідного фонду Івано-Франківської області нараховує 482 території та об'єкти загальною площею 218,9 тис. га, або 15,7 \% від площі області, зокрема: 33 об'єкти загальнодержавного значення площею 131,6 тис. га; 449 об'єктів місцевого значення площею 87,26 тис. га. Природно-заповідний фонд області репрезентують: один природний заповідник "Горгани" (площею 5,3 тис. га); п'ять Національних природних парків (НПП) (площею 120,3 тис. га) (Карпатський НПП, НПП "Гуцульщина", Галицький НПП, НПП "Синьогора", НПП "Верховинський"); три Регіональні ландшафтні парки (площею 38,4 тис. га); а також: 64 - Заказники (площею 45,93); 189 - Пам'яток природи (площею 1,2 тис. га); 7 Дендрологічних парків (площею 0,15 тис. га); 9 - Парків-пам'яток садово-паркового мистецтва (площею 0,094 тис. га); 196 - Заповідних урочищ (площею 7,3 тис. га)" [18].

Обласна державна адміністрація здійснює відповідну роботу щодо заповідання пралісів та квазіпралісів, створення нового Національного природного парку "Чорний ліс". Погоджено розширення Національного природного парку "Верховинський" шляхом вилучення земель лісогосподарського призначення державної власності державного підприємства "Верховинське лісове господарство" (Буркутське лісництво, кв. 14-24) загальною площею 1695,5 га 3 метою надання їх у постійне користування Національному природному парку "Верховинський".

Щодо фізико-географічного районування заповідних об'єктів Івано-Франківщини, більшість із них (62\%) розташована у гірській частині, $25 \%$ - у Передкарпатті та $13 \%$ - у рівнинній частині (рис. 1). Структуру територій та об'єктів природно-заповідного фонду Івано-Франківської області за кількістю (шт.) відображено на рис. 2. За даними автора Н. Паньків (2008): "Природоохоронними та рекреаційними установами 
місцевого значення $є$ регіональні ландшафтні парки "Дністерський", уздовж Дністра, на території Тлумацького і Городенківського районів, і "Поляницький" - на території Болехівської міської ради.

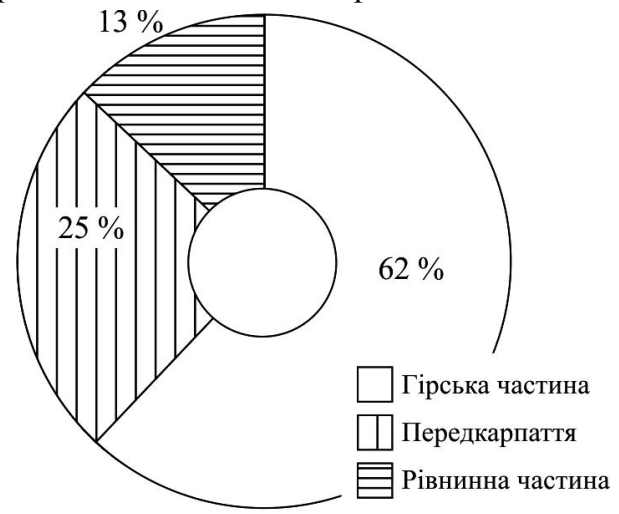

Рис. 1. Фізико-географічне районування заповідних об'єктів Івано-Франківщини

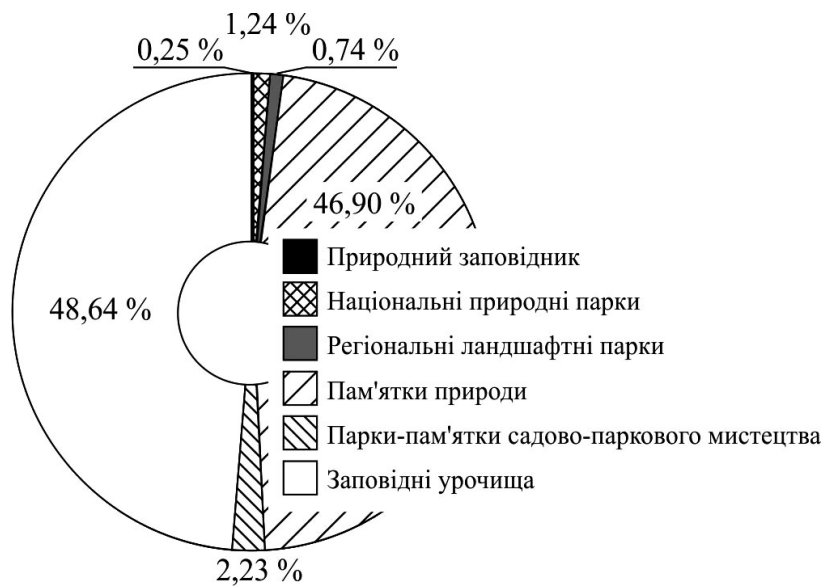

Рис. 2. Структура території та об'єктів природно-заповідного фонду Івано-Франківської області за кількістю (шт.)

Окрім цього, в області зосереджені великі за площею заповідні території: ландшафтний заказник загальнодержавного значення "Грофа", ботанічні заказники загальнодержавного значення "Яйківський", "Тавпиширківський" та ін. Рогатинське Опілля репрезентує Галицький національний природний парк, лісові заказники місцевого значення "Журити" i "Журавенківський", Покутсько-Буковинські Карпати - національний парк "Гуцульщина", Полонинсько-Чорногірську область - гідрологічний заказник місцевого значення "Piка Чорний Черемош", Рахівсько-Чивчинську область ландшафтний заказник місцевого значення "ЧивчиноГринявський", Сколівські Бескиди - Поляницький регіональний ландшафтний парк, ботанічні заказники місцевого значення "Магура" та "Федів", загальнозоологічний заказник місцевого значення "Гирява" та ін. Унікальними також є ботанічні заказники загальнодержавного значення "Княждвірський", де охороняється тис ягідний; "Скит "Манявський", на території якого росте модрина польська; "Яйківський", створений для охорони сосни кедрової європейської; комплексна пам'ятка природи "Скелі Довбуша" з унікальними скельними утвореннями; степові резервати "Масьок", "Касова гора", "Чортова гора" з реліктовою рослинністю (ковила, ясенець білий, осока низька, фіалка Джоя) та ін." [12].

Загалом серед найперспективніших осередків, які мають високий потенціал для розвитку екологічного туризму в області: Косівський, Долинський, Надвірнянсь- кий, Городенківський і Верховинський райони та територія Яремчанської міської ради. Зокрема, найбільша кількість природоохоронних об'єктів зосереджена на території Яремчанської міської ради (59,8 \%), а найменша - у Долинському районі (10,6 \%) [20].

Важливе рекреаційне туристичне значення на ІваноФранківщині мають Національні природні парки області, хоча їх основне призначення - збереження типових для цієї зони об'єктів, а також збереження та відновлення цінних та унікальних природних комплексів чи їх важливих складових елементів. Зокрема:

1) Карпатський національний природний парк площею 50495,0 га, є перший і один 3 найбільших в Україні національних природних парків. Його створено ще у 1921 р. для збереження унікальних лісових екосистем Центральної Європи. Його територія простягається на 55 км 3 півночі на південь і на 20 км із заходу на схід на північно-східних схилах Українських Карпат. Переважна частина території Парку розташована в межах абсолютних висот 500-2061 м н.р.м. а найвища точка України - вершина гори Говерли (2061 м н.р.м.) - розташована в межах Парку.

На території національного парку для відвідувачів облаштовано рекреаційні зони та місця відпочинку та прокладено низку екологічних стежок. Як зазначено на Офіційному сайті Карпатського НПП, це: "Реабілітаційний центр для тварин на базі вольєрного господарства; водоспад "Дівочі сльози"; На гору Маковиця; До найстарішого дерева; Стежка Довбуша; Урочище Женець - водоспад Гук; Урочище Вередівський - гора Хом'як; На гору Говерла; На гору Піп Іван; Наш друг природа; Урочище Женець - гора Явірник; Урочище Женець - гора Хом'як; Урочище Бредулець - полонина Ягідний; Село Дземброня - гора Піп Іван; Село Бистрець - гора Ребра - гора Шпиці - полонина Гаджина полонина Маришевська; Село Бистрець - гора Менчул - село Дземброня; Вокзал с. Вороненко - урочище Ломпарівка - урочище Припір - урочище Буковина". Загалом до найцікавіших об'єктів Парку належать: Екотуристичний візит - центр Карпатського національного природного парку; Реабілітіційний центр для тварин на базі вольєрного господарства Яремчанське природоохоронне науково-дослідне відділення (ПОНДВ); Пасіка; Босонога стежка; Парк-музей "Карпати в мініатюрі"; Водоспад "Пробій" та болото "Рудяк" [1].

2) Національний природний парк "Гуцульщина" площею 32271,0 га, розташований у мальовничій, вкритій лісом, частині Покутсько-Буковинських Карпат. Уся територія Парку пронизана численними водоймами, найбільші з них річки Лючка, Пістинька, Рибниця, Черемош, які є правими притоками річки Прут. У гірській частині Парку є велика кількість водоспадів, які є популярними серед туристів місцями відпочинку. А поблизу південної межі Парку протікає річка Черемош, яка приваблює любителів водних видів спорту та відпочинку.

Територією Парку прокладено низку еколого-пізнавальних стежок, з детальним описом еколого-пізнавальних стежок можна ознайомитись на Офіційному сайті НПП "Гуцульщина", зокрема: "На гору Овид та БабаЖбир"; "До сірководневого джерела на р. Волійці"; "До оглядового майданчика на гору Острий"; "На хребет Каменистий"; "На хребет Брусний до каменя Довбуша"; "На гору Михалків"; "По Дубині". На території НПП 
"Гуцульщина" 32003 р. діє Туристично-мистецький комплекс - "Маєток Святого Миколая" [3].

3) Галицький Національний природний парк - площею 14684,8 га, розташований на межі Українських Карпат (область Передкарпаття) та південно-західної частини Східно-Свропейської рівнини (область Опілля Західноукраїнської провінції Лісостепової зони), що зумовило його велике біологічне та ландшафтне різноманіття.

Територією Парку прокладено туристичні маршрути та еколого-пізнавальні стежки, як зазначено на Офіційному сайті Галицького НПП, це: "Княжа криниця Замкова гора"; "По Діброві"; "Вздовж Бурштинського водосховища"; "На риборозплідні ставки"; "До Галичинських печер"; "Ворониця - Сімлин"; "Вздовж водосховища на Касову гору". Також, для зручності відвідувачів Парку, облаштовано рекреаційні пункти, зокрема: "На Сімлин"; "Рекреаційно-туристичний комплекс "Підгірки"; "Верби"; "На р. Дністер поруч столітнього мосту"; "Колодіїв"; "Лісовий затишок"; "Під Дугласією" та ін." [2].

4) Національний природний парк "Синьогора" площею 10866 га, розташований в околицях села Гута, на території Богородчанського району. Раніше понад десять тисяч гектарів карпатських лісів, розташованих поблизу, використовували як президентську резиденцію. Однак у 2009 р., згідно з указом Президента Украіни було створено НПП "Синьогора": "3 метою збереження, відтворення та раціонального використання типових і унікальних природних комплексів гірського масиву Горгани (Українські Карпати), що мають важливе природоохоронне, наукове, естетичне, рекреаційне та оздоровче значення" [8].

5) Національний природний парк "Верховинський" - площею 12022,9 га, розташований на території Верховинського району Івано-Франківщини, в межах Голошинської та Зеленської сільських рад. На території парку облаштовано 25 рекреаційних місць, 3 їхнім детальних описом можна ознайомитись на Офіційному сайті Парку, серед них: "Кляуза Лостун; урочище Штефулець; урочище Штефулець; Скала в урочищі Прелучний; Сірководневе мінеральне джерело в урочищі Прелучний; Потік Лостунець; Плоскогір'я Палениця; Пам'ятка природи Скала Баби; Озеро в урочищі Чемірне; Монастир Дукінський; Кляуза в урочищі Балтагора; Гуцульська садиба та багато інших. Територією парку прокладено також шість еколого-пізнавальних туристичних маршрутів: "Перкалаба-Пробійнівка"; "СкалаБаби"; "Цісаревича Рудольфа"; "Кляуза Лостун"; "Чемірне"; "Стежками Лесі Українки" [4].

Безумовно, важливим екологічним фактором, що приваблює туристів відвідати Івано-Франківщину, є наявність Національних природних парків, однак доцільне також використання таких об'єктів області, як: Майбутній "Парк льодовикового періоду" поблизу села Старуня Богородчанського району області, де під час розкопок у 1929 р. було знайдено добре збережені рештки мамонта та волохатих носорогів, що загинули близько 20 тис. років тому. Незабаром тут буде облаштовано туристично-рекреаційний комплекс, який сприятиме промоції регіону. Окрім цього, поблизу міста Галич $є$ унікальні поселення епохи середнього і пізнього палеоліту (від 120 до 10 тис. років тому), а також геоекологічний полігон "Обсерваторія на горі Піп Іван" та багато інших [12].
Активно розвивається атракційна туристична інфраструктура в області: відкрито річковий порт "Раковець" (с. Раковець Городенківського району), парк-музей "Карпати в мініатюрі" (м. Яремче), оглядовий майданчик на ратуші та туристично-інвестиційний центр (м. Івано-Франківськ), Центр спадщини Вигодської вузькоколійки (с-ще Вигода Долинського району), туристично-інформаційний центр (м. Коломия), комплекс "Полонина перці" (с. Яблуниця Яремчанської міської ради), візит-центри (м. Галич і с. Ільці Верховинського району), туристично-інформаційний центр (м. Косів), гуцульську сироварню (с. Яворів Косівського району), етнопарк "Гуцул Ленд" (ГК "Буковель"), музеї та інші об'єкти.

У сучасних умовах пандемії коронавірусу та необхідності дотримуватися карантинних обмежень і соціальної дистанції, зокрема під час відпочинку на ІваноФранківщині, доцільно розвивати саме зелений (сільський) та екологічний туризм. Нещодавно було розроблено "Методичні рекомендації (Протокол) з надання послуг сільського зеленого туризму (сільської гостинності) у корона- та посткоронавірусний період" у якому зазначено, що: "У рамках 2020 - року розвитку туризму у сільських територіях, ГО "Спілка сприяння розвитку сільського зеленого туризму в Україні" у співпраці 3 National Tourism Organization of Ukraine долучилася до глобальної ініціативи Всесвітньої Ради з Подорожей та Туризму (WTTC) \#ПодорожуйБезпечно (Safe travels). Експертами Спілки та Проекту СC Geographical Indications in Ukraine/Географічні зазначення в Україні разом 3 партнерами було розроблено Протокол для адаптації роботи садиб з пріоритетом на захист здоров'я людей та 3 метою ефективного пом'якшення наслідків пандемії COVID-19. Його імплементація дасть змогу господарям сільських садиб, які надають послуги сільського зеленого туризму: вжити ефективних практичних заходів для зменшення ризиків захворювання на корона вірусну хворобу COVID-19 як господарів сільської садиби, членів їхніх родин, так і туристів; отримати додаткову конкурентну перевагу, гарантуючи туристу посилену увагу до захисту його здоров'я; підвищити якість послуг сільського зеленого туризму (сільської гостинності) з урахуванням санітарно-гігієнічних вимог та вимог соціального дистанціювання" [14].

\section{Висновки}

Природні умови та наявність великої кількості об'єктів природно-заповідного фонду в Івано-Франківській області сприяють розвитку різноманітних форм екологічного туризму. Найбільший потенціал для розвитку цього виду туризму $є$ на території Косівського, Долинського, Надвірнянського, Городенківського і Верховинського районів та території Яремчанської міської ради.

Базовою складовою частиною розвитку екотуризму мають стати численні екологічні стежки та еколого-пізнавальні туристичні маршрути, прокладені на території Івано-Франківщини. Розвитку різних форм активного туризму, зокрема, пішохідного, кінного та велотуризму, скелелазіння, спелеотуризму, паропланінгу та Zipline (екстремальні спуски на спеціальному спорядженні), сприяє наявність гірських карпатських парків. Для розвитку водного виду туризму найбільше ресурсів у Карпатському та Вижницькому національних парках. А на- 
ціональні парки "Сколівські Бескиди", "Ужанський" та "Гуцульщина" мають стати осередками етнографічного туризму регіону [21].

Сільський зелений туризм Івано-Франківщини має сприятливі передумови для розвитку, адже в області $є$ пам'ятки історії та культури світового рівня, унікальні природні ландшафти. Однак доречно розвивати в області такі напрямки туристичної діяльності, як інтерактивні скансени, агроготелярство, контактні зоопарки, іпотерапія та апітерапія, а також відвідування історичних сільських місцевостей та участь в етнофестивалях і різноманітних майстер-класах з виготовлення народних ремесел, оскільки місцеве населення досі зберігає багату матеріально-духовну спадщину, особливий давньоукраїнський колорит, який наповнений самобутніми обрядами, одягом, побутом, ремеслами та архітектурою, що сприятиме розвитку в регіоні також етнографічного туризм.

До прикладу, у селі Яблуниці відкрили осередок гуцульської культури "Полонина Перці", де можна побачити та відчути справжнє життя гуцулів, дізнатись про їхні звичаї та традиції, приміряти автентичний святковий одяг, скуштувати гуцульські страви та послухати їхніх пісень. Тут гостинно, цікаво, атрактивно та пізнавально, тому це місце приваблює туристів [13].

Усе це зумовить розвиток "безпечного" туризму в області, що буде сприяти збереженню навколишнього середовища та раціональному використанню туристично-рекреаційних ресурсів Івано-Франківщини та забезпечить роботою місцевих мешканців, що зумовить економічне зростання регіону загалом.

\section{References}

1. Ekolohichni stezhky. (2020). Ofitsiinyi sait Karpatskoho NPP. Retrieved from: http://cnnp.if.ua/ekoturyzm/ecost. [In Ukrainian].

2. Ekolohoho-piznavalni stezhky. (2020). Halytskyi Natsionalnyi pryrodnyi park. Retrieved from: https://nnph.if.ua/category/3-ecological-educational-activities/4-eco-routes/. [In Ukrainian].

3. Ekolohoho-piznavalni stezhky. (2020). Natsionalnyi pryrodnyi park "Hutsulshchyna". Retrieved from: https://nnph.if.ua/category/3-ecological-educational-activities/4-eco-routes/.

[In Ukrainian].

4. Ekoloho-piznavalni turystychni marshruty. (2020). Natsionalnyi pryrodnyi park "Verkhovynskyi". Retrieved from: http://nppver.at.ua/news/ekologo_piznavalni_turistichni_marshruti ta_stezhki/2015-11-03-352. [In Ukrainian].

5. Grytsyuk, M. Yu., \& Hrytsiuk, Yu. I. (2013). Metody kompleksnoho otsiniuvannia variantiv stratehichnoho rozvytku turystychnoi haluzi. Bulletin of the National University "Lviv Polytechnic". Series of Computer Sciences and Information Technologies, 672, 110-119. Lviv: Publishing NU "Lvivska politekhnika". [In Ukrainian].
6. Horishevskyj P. V., Vasyliev, V. P., \& Zinko, Yu. V. (2003). Silskyj zelenyj turyzm: orhanizatsiia hostynnosti na seli: pidruchnyk. Ivano-Frankivsk: Misto-N, 158 p. [In Ukrainian].

7. Hrytsiuk, Yu. I., \& Grytsyuk, M. Yu. (2016). Modeliuvannia stratehii povedinky konkurentnykh firm na rynku nadannia turystychnykh posluh. Bulletin of the National University "Lviv Polytechnic". Series of Information Systems and Networks, 854, 5062. Lviv: Publishing NU "Lvivska politekhnika". [In Ukrainian].

8. Natsionalnyi pryrodnyi park "Synohora". (2020). Retrieved from: https://uk.wikipedia.org/wiki/Natsionalnyi_pryrodnyi_park_"Synohora". [In Ukrainian].

9. Ofitsiinyi sajt "Vidpochynok v Karpatakh - Karpatyinfo". (2020). Retrieved from: http://www.karpaty.info/ua/. [In Ukrainian].

10. Ofitsiinyi sajt Holovnoho upravlinnia z pytan turyzmu, yevrointehratsii, zovnishnikh zviazkiv ta investytsij. (2020). Retrieved from: http://frtt.if.gov.ua. [In Ukrainian].

11. Ofitsiinyi sajt Spilky spryiannia rozvytku silskoho zelenoho turyzmu v Ukraini. (2020). Rezhym dostupu: https://www.greentour.com.ua/region/ivano-frankivska. [In Ukrainian].

12. Pankiv, Nataliia. (2008). Pryrodoresursnyi potentsial rozvytku ekolohichnoho turyzmu Ivano-Frankivskoi oblasti. Visnyk Lvivskoho universytetu. Seriia mizhnarodni vidnosyny, 24, 230-233. [In Ukrainian].

13. Polonyna Pertsi. (2020). Neimovirna podorozh v hutsulskyi svit. Etnosvit. Retrieved from: https:/etnosvit.com/uk/polonynapertsi/). [In Ukrainian].

14. Protokol. (2020). Metodychni rekomendatsii z nadannia posluh silskoho zelenoho turyzmu (silskoi hostynnosti) u korona- ta postkoronavirusnyi period. Retrieved from: http://www.ntoukraine.org/.../11_URGTU_SP_Ukrainian.... [In Ukrainian].

15. Rutynskyj, M. J. (2004). Ivano-Frankivshchyna: terytorialna orhanizatsiia turystychnoho kompleksu ta struktura suchasnoho turystychnoho produktu rehionu. Naukovi zapysky Vinnytskoho derzhavnoho pedahohichnoho universytetu imeni M. Kotsiubynskoho. Seriia: Heohrafiia, 7, 177-184. [In Ukrainian].

16. Rutynskyj, M. J., Zinko, Yu. V. (2006). Silskyj turyzm: navch. posib. Kyiv: Znannia, 271 p. [In Ukrainian].

17. Stetsiuk, O. (2012). Suspilno-heohrafichnyi analiz rozvytku silskoho zelenoho turyzmu v Ivano-Frankivskii oblasti. Visnyk Lvivskoho universytetu. Seriia mizhnarodni vidnosyny 29(1), 203-212. [In Ukrainian].

18. Stratehiia rozvytku Ivano-Frankivskoi oblasti na 2021-2027 roky. (2020). Retrieved from: https://orada.if.ua/wp-content/uploads/2020/01/Stratehiia-rozvytku-Ivano-Frankivskoi-oblasti.pdf. [In Ukrainian].

19. Vlasenko, I. V., \& Ivashchenko, H. V. (2017). Funktsionuvannia silskoho zelenoho turyzmu v umovakh rynkovoi ekonomiky Ukrainy. Ekonomichna stratehiia i perspektyvy rozvytku sfery torhivli ta posluh, (25), 218-233. [In Ukrainian].

20. Zberezhennia ta rozvytok pryrodno-zapovidnoho fondu na Prykarpatti. (2019). Ofitsiinyi sait Ivano-Frankivskoi ODA. Retrieved from: http://www.if.gov.ua/news/23774. [In Ukrainian].

21. Zinko, Yu. (2013). Ekolohichni aspekty rekreatsiino-turystychnoi diialnosti v Ukrainskykh Karpatakh. Ekolohichna sytuatsiia $v$ Karpatakh: na pochatku KhKhI stolittia: suchasnyi stan i shliakhy vyrishennia problem: Materialy mizhnar. konf. Lviv, 56-64. [In Ukrainian].

N. E. Pankiv

Lviv Polytechnic National University, Lviv, Ukraine

\section{PROSPECTS FOR THE USE OF TOURIST AND RECREATIONAL RESOURCES FOR THE DEVELOPMENT OF GREEN (RURAL) AND ECOLOGICAL TOURISM IN IVANO-FRANKIVSK REGION}

The paper investigates the tourist and recreational resources of Ivano-Frankivsk region and identifies prospects for their use for the development of green (rural) and ecological tourism in the region. In the course of research rural green tourism was found to have favourable conditions for its development, as there are world-class historical and cultural monuments, and unique natural landscapes in the region. The most popular recreation centers among tourists are Yaremche, Verkhovyna and Kosiv districts, in particular, their mountainous private areas, where there is a developed network of agro-villages (in general, in the region - about 800 houses) with 
different prices. It is revealed that natural conditions and the presence of a large number of objects of the nature reserve fund in Ivano-Frankivsk region, namely 482 territories and objects, the area of which is 218.9 thousand hectares, which is $15.7 \%$ of the area of the region, contribute to the development of a wide range of forms of ecological tourism. The most promising centers that have a high potential for the development of this type of tourism in the region are as follows: Kosiv, Dolyna, Nadvirna, Horodenka and Verkhovyna districts and the territory of Yaremche Municipality. Ivano-Frankivsk region is found to be formed by various ethnographic districts such as Pokuttya, Hutsul, Boykiv and Opillya. The indigenous population still retains a rich material and spiritual heritage, a special ancient Ukrainian flavour, which is filled with original rites, clothing, life, crafts, architecture, being certainly attractive to many tourists, which contributed to the development of ethnographic tourism in the region. Therefore, it is advisable to introduce new tourist activities for the region, such as agro-hotels, interactive open-air museums, contact zoos, hippotherapy and apitherapy, as well as stays in historic villages, participation in local festivals, and various master classes on folk crafts. All this will lead to the development of safe tourism in the region, which will contribute to the preservation of the environment and rational use of tourist and recreational resources of Ivano-Frankivsk region and provide work for local residents, which in turn will lead to economic growth in the region as a whole.

Keywords: natural resource potential; recreational value; country territories; objects of the nature reserve fund; development of safe tourism. 